Journal of the Egyptian Society of Parasitology, Vol.43, No.3, December 2013

J. Egypt. Soc. Parasitol., 43(3), 2013: 669 - 678

\title{
HOUSE DUST MITES: A RISK FACTOR TO BE CONSIDERED FOR OCCUPATIONAL SAFETY OR SOURCE OF WORK-RELATED ALLERGENS
}

\section{By}

AHMED MEGAHED AHMED SALEH ${ }^{1}$, HISHAM ABD EL-RAOUF ALI ${ }^{2}$, SALWA ABDALLA MOHAMED AHMED ${ }^{3}$, NAEMA MAHMOUD MOHAMMAD ${ }^{4}$ AND TOSSON A. MORSY ${ }^{5}$

Military Institute of Health and Epidemiology $y^{1,3,4}$ and Medical Surgical Nursing $^{3}$, The Military Medical Academy ${ }^{1,2,3,4}$ and Department of Parasitology, Faculty of Medicine, Ain Shams University, Cairo 11566 ${ }^{5}$, Egypt

Abstract

House dust mites (HDM) can be found worldwide where human beings live independent from the climate and are a major source of multiple allergens. Mite allergens sensitize and induce perennial rhinitis, asthma, or atopic dermatitis in a large portion of patients with allergic disease particularly children. There is convincing evidence that avoidance of mite allergen can effectively reduce allergic symptoms.

This study examined dust from a military hospital and the private home of some nursing staff. A total of seven species of mites belonging to six genera were recovered. The commonest species was Dermatophagoides farinae followed by D. pteronyssinus and the lowest Laelaps nuttalli. Besides, the $7^{\text {th }}$ mite or Parasitus consanguineous live free on dust as a bio-control agent of mites. The presence of mites in and out doors in a hospital and dwellings of medical personnel pave the way to consider HDM as occupational or nosocomial Allergens.

Key words: House dust mites, Hospital, Private dwellings, seven species of mites.

\section{Introduction}

The house dust mite (HDM) is a cosmopolitan guest in human habitation. Dust mites feed on organic detritus as flakes of shed human skin and flourish in the stable environment of dwellings. HDM are the common cause of asthma and allergic symptoms all over the world particularly in children (Yuenyongviwat et al, 2013). Mite's gut contains potent digestive enzymes (notably proteases) that persist in their feces and are major inducers of allergic reac- tions such as wheezing. The mite's exoskeleton can also contribute to allergic reactions. The HDM survives in all climates, even at high altitude, and thrive in the indoor environment provided by homes, specifically in bedrooms and kitchens (Arbes et al, 2003). Dust mites survive well in mattresses, carpets, furniture and bedding, with figures around 100-500 animals/g dust. Even in dry climates, house dust mites survive and reproduce easily in bedding (especially in pillows) that takes 
up moisture from body contact (ElZemity et al, 2006). HDM allergens are among the most common triggers of asthma (Adgate et al, 2013). There are at least 15 mite allergens which are subdivided into groups. Group 1 \& 2 allergens are the most problematic. G1 consists of proteins with a catalytic activity, for example Der $p 1$ (Dermatophagoides pteronyssinus G1) allergen is a cysteine protease, as is its American counterpart $\operatorname{Der} f 1$ (D. farinae $\mathrm{G} 1)$. $\mathrm{G} 2$ are proteins important for mite. Proteins from other groups affect only few patients (Park et al, 2013).

The mean attributable fraction of adult asthma due to atopic sensitization was $30 \%$ and $18 \%$ for sensitization to dust mites. Taken into consideration this could mean that as many as 1.2 billion people have some forms of the chronic sensitization to dust mites (Ramìrez-Heredia et al, 2013).

In Egypt, many studies were done on HDM. Some of the surveys were selected (Gamal-elddin et al, 1982) in Tanta City (39\%), Morsy et al. (1994) in Qualyobia Governorate, Bakr et al. (1995) in Shebin El-Kom City, Yassin and Rifaat (1997) in Esna City, Kena Governorate, Sadaka et al. (2000) in Alexandria City with an average of 83.79\%, Saad et al. (2006) in Zagazig City, El Shazly et al. (2006) and ElNahas et al. (2007) in Dakahlia Governorate $59.9 \%$ in the urban houses and $46.3 \%$ in rural one. On the other hand, none of the Egyptian authors dealt with HDM from nosocomial point of view.

The present study aimed to evaluate of HDM in a Military Hospital and in some nursing staff private homes.

\section{Subjects, Materials and Methods}

Collection of dust samples: Dust samples were obtained once a week from major foci indoor (floor, carpets, mattresses, bedding, kitchen, structures where rat nets are located) during one month period 2013. A vacuum equipped with a dust trap, one square meter of each place was vacuumed for one minute. Samples were put in plastic bags and stored at $4^{\circ} \mathrm{C}$ to avoid proliferation (Morsy et al, 1994).

Isolation and identification: Ten milliliters of $90 \%$ lactic acid were added to $100-250 \mathrm{mg}$ of dust sample. Mixture was boiled \& diluted with $90 \mathrm{ml}$ distilled water (Morsy et al, 1995). They were mounted in 2 drops of Hoyer's medium (Arabic gum 30gm, chloralhydrate $200 \mathrm{gm}$, glycerin $20 \mathrm{ml}$, water $500 \mathrm{ml}$ ) for study (El-Sherbiny et al, 2010). Mites against contrasting blue colored field were removed by a fine needle and identified by local and international standard keys. Data were expressed as number of mites/gm. dust.

\section{Results}

The recovered dust mites were:

1- Dermatophagoides farinae (Acarina, Pyroghphidae),

2- Dermatophagoides pteronyssinus (Acarina, Pyroghphidae),

3- Ornithonyssus bacoti (synonym: Liponyssus bacoti) (Macronyssidae), 4-Acarus siro (Acarina, Acaridae),

5- Tyrophagus putrescentiae (Acarina, Acaridae),

6- Laelaps nuttalli (Acarina, Laelapidae),

7- Parasitus consanguineus (Acarina, Parasitidae). 
Table 1: Distribution of mites within positive patient sites

\begin{tabular}{|c|c|c|c|c|c|}
\hline \multirow{2}{*}{ HDM species } & \multirow[t]{2}{*}{ Sites of collection } & \multicolumn{2}{|c|}{ Patients homes } & \multicolumn{2}{|c|}{ Test } \\
\hline & & No. & $\%$ & $\chi^{2}$ & $\mathrm{P}$ value \\
\hline Dermatophagoides farinae & \multirow{2}{*}{$\begin{array}{l}\text { Indoors (bedrooms, mattress carpets, } \\
\text { living rooms...etc. }\end{array}$} & 44 & 73.3 & \multirow{6}{*}{64.7} & \multirow{6}{*}{$0.000 * *$} \\
\hline D. pteronyssinus & & 33 & 55.0 & & \\
\hline Tyrophagus putrescentiae & outdoor dust, garden, stored materials & 33 & 55.0 & & \\
\hline Acarus siro & Free living on decaying matters or flour & 22 & 36.7 & & \\
\hline Liponyssus bacoti & Rodents \& rodents' infested areas & 11 & 18.3 & & \\
\hline Laelaps nuttalli & Rodents and birds infested areas & 9 & 15.03 & & \\
\hline
\end{tabular}

NB: Parasitus consanguineus feed on acari mites and live on floor dust as a bio-control agent of mites.

\section{Discussion}

Nowadays, the house dust mites have showed themselves as one of the health problems worldwide represented by more than 50.000 species. They are non-welcomed guests in human habitation causing several forms of allergic diseases, including hay-fever, asthma, eczema and aggravate atopic dermatitis. Mites are usually found in warm and humid locations, including beds. The inhalation of mites during sleep exposes the human body to some antigens that eventually induce hypersensitivity reaction. Dust mite allergens are among the heaviest dust allergens. Duration of life cycle of dust mites is directly dependent on temperature. The microhabitats where mites are found in homes are not of uniform temperature (mattress vs. floor) or temperature can fluctuate during short periods within a microhabitat (Solarz, 2009).

The HDM have to be considered in the differential diagnosis of allergy particularly in children. The dust mites are the main factor involved in respiratory disorder (El-Ghitany and Abd ElSalam, 2012). The bronchial asthma constitutes one of the major health problems as HDM are common inhalant allergens, which cause atopic disease episodes including bronchial asth- ma, atopic dermatitis and allergic rhino-conjunctivitis (Becker et al, 2012).

Like most of the other types of allergy, treatment of mite allergy starts with avoidance. There is a strong body of evidence showing that avoidance must be helpful in patients with atopic dermatitis triggered by mites' exposure. Regular washing of mattresses and blankets with hot water can help in this regard. Antihistamines are also useful; Cetirizine, for example reduced allergic symptoms of patients (Zieglmayer et al, 2005).

In Egypt, Frankland and El-Hefny (1970) were the first to report the prevalent house dust mite; Dermatophagoides farinae as a cause of inhalant allergic problem particularly in children.

Mazyad et al. (2006) studied the effect of Juvenile hormone analogue, Admiral "pyriproxyfen", which acts as a protein denaturing agent, on the protein patterns of $D$. farinae on allergic reactions in patients with HDM asthma, and in mice injected twice (within 10 days) with mite crude extracts. They found that Injection of mice with normal adult extracts of $D$. farinae resulted in significantly higher levels of histamine, S-IgE and ECP than in the check animals. 
In the present study, seven species of mites belonging to seven species were recovered from the examined site. They were Dermatophagoides farinae, D. pteronyssinus, Ornithonyssus bacoti (synonym: Liponyssus bacoti), Acarus siro, Tyrophagus putrescentiae, Laelaps nuttalli, and Parasitus consanguineus.

The $D$. farinae was the most dominant mite species found in the indoor collected house dust samples. However, the most prevalent mite in the outdoors areas of the study was $A$. siro followed by $O$. bacoti. Reeves et al. (2007) collected tropical rat mites (=Liponyssus bacoti) from the Norwegian rats Rattus norvegicus and the Egyptian Rattus rattus as well as in all rodent infested areas throughout 14 Egyptian Governorates. They demonstrated one Bartonella sp. and two Rickettsia spp., from eight pools of mites.

Shanbaky and Hammad (1989) from manure in two slaughterhouses in Cairo and Giza collected mites on 2 successive years in order of abundance were of families Macrochelidae (M. mascaedomesticae, M. merdarius and Glyptholaspis confuse), Parasitidae (P. consanguineus $)$ and Uropodidae $(U .=F u s-$ curopoda marginata, respectively. The macrochelid and parasitid species generally attained their highest populations in winter and/or spring from December to May. However, that of the uropodid species was reached mainly in the late spring, summer and autumn from May to October.

Netusil et al. (2005) in Czech Republic stated that Ixodidae Ticks are the primary vectors of the Borrelia burg- dorferi sensu lato, which causes the Lyme disease. They found mites positive for the presence of DNA of $B$. burgdorferi sensu lato and suggested the possible participation of Parasitidae mites in borrelial circulation in nature.

Green and Woolcock (2006) stated that $T$. putrescentiae is an important source of allergen and should be considered whenever $D$. pteronyssinus was thought to be the health problem. Abdel-Salam (2013) found that the storage mite, $T$. putrescentiae, detected in the samples collected from stored products and house dust, was one of the major causes of allergic disorders in children.

On the other hand, Acarus siro is a free living mite on cheese or ground flour and T. putrescentiae is a free living one on stored seeds as wheat grains (El Beshbishi et al, 2005). However, the dust mites' A. siro, L. destructor, $T$. putrescentiae, and $D$. pteronyssinus have common allergenic epitopes as the nematode Anisakis simplex (Bernardini et al, 2005). This nematode parasite is encountered in Egypt (Arafa et al, 2009). Dermatophagoides pteronyssinus and $D$. farinae are very common in Egypt (Yassin, 2011) as a hypersensitive important factor for persistent and severe forms of asthma particularly in schoolchildren (Adham and Tawfik, 2012).

Besides, many Egyptian authors previously mentioned in the text reported that the house dust mites is still one of the many causes of allergy, particularly atopic dermatitis, respiratory allergy, bronchitis, skin rash and some-times fever. Also, double manifestations with fever were reported in children, with 
elevation in $\operatorname{IgG}$ and $\operatorname{IgM}$, but not in IgA. However, high significant elevation was in IgE.

Abroad, Szlendak and Lewandowski (2009) in Poland stated that development and reproduction of the predatory mite Parasitus consanguineus (Parasitidae) reared on a diet of $1^{\text {st }}$ and $2^{\text {nd }}$ instars of Megaselia halterata (Diptera: Phoridae) or Lycoriella ingenua (Diptera: Sciaridae) proved P. consanguineus to be a promising bio-control agent. Hatzivlassiou et al. (2010) in England stated that allergen inhalation challenge in asthma may induce both early and late asthmatic reactions. The early one was IgE and mast cell dependent. They concluded that identify the allergen specificity of late asthmatic reactions indicated that factors independent of IgE, and relevance both to the understanding of the allergen-induced airway responses in asthma and the need for homogeneity in inhaled-allergen challenge in asthma. Salehi et al. (2011) in Iran compared between dwellings' age and some other home characteristics in asthmatic and allergic rhinitis children, who had positive skin prick test to mite and cockroaches, with allergic patient with negative skin test. The thirty-six asthmatic and allergic rhinitis children with skin prick positive to mite and cockroach allergens, and thirty-four allergic rhinitis and asthmatic children with negative skin prick test to such allergens were also enrolled. Data on dwelling, included homes' age, kind of carpeting, floor of home and number of rooms in the building. The mean buildings; age was higher in the group of children sensitive to mite and cock- roach $(22.4+/-12.9$ versus $16.3+/-13.9$ years), but without significant. However, when patients sensitive to mite only were compared to control patients, the difference was significant $(\mathrm{P}=0.025)$. There was no significant difference in the number of floor, rooms, kind of carpet and other features of building between cases and controls. There was a significant relationship between mite allergy and building age that contributed to the society allergy control policy. Macan et al. (2012) in Croatia found pyroglyphid mites or their allergens in various workplaces, but clinically relevant exposures were observed in hotels, cinemas, schools, day-care centers, libraries, public transportation (buses, trains, taxies, and airplanes), fishingboats, submarines, poultry farms, and churches. They considered this an occupational risk included factors relevant for indoor mites (climate, building characteristics, and cleaning schedule). They added that occupational physicians should assess exposure risk at work, propose proper protection, provide vocational guidance to persons at risk and conduct pre-employment and periodic examinations to diagnose new allergy cases. Valmonte et al. (2012) in Philippines reported the presence of multiple cross-reactive antigens in HDM and Al extracts, and that identification of these molecules might provide basis for designing novel diagnostic and therapeutic strategies for HDM allergy. Carrard and Pichler (2012) in Germany found HDM scales in mattresses, upholstered furniture and carpets, as clinical picture with slowly aggravating complaints led quite often 
to a delayed diagnosis accidently done on the occasion of a wider spectrum of allergy skin testing. The beginning of a medical therapy with topical steroids as nasal spray or inhalation leads to a fast relief of the complaints. The frequent ventilation of the dwelling with cold air in winter time caused a lower indoor humidity. Covering encasings on mattresses, pillow, and duvets reduced the possibility of chronic contact with mite allergens as well as the weekly changing bed linen. They added that specific immunotherapy with extracts of house dust mites showed good results in children and adults. Feng et al. (2012) in China studied the pollution of dust mite allergens in the houses of 30 families and their infection to young allergic asthma patients in Shanghai. They reported significant correlation between the number of Der 1 allergens collected from floor surfaces and the number of Der 1 allergens collected from bed surfaces. They added that relative humidity in dwellings was the commonest influential to the allergen levels and that the opening windows and periodic cleaning of beddings might be effective in removing the dust mite allergens.

Szafranek et al. (2013) in Poland reported that $P$. bituberosus (Acari: Parasitidae) is one of the predatory mite sp. inhabiting mushroom houses, preying on pests of mushroom namely rhabditid nematodes, pygmephorid mites, and sciarid and phorid fly larvae. They stated that $P$. bituberosus proved to be a biocontrol agent against pathogenic mites.

Regarding nosocomial infection, Regan et al. (1987) reported an outbreak of pigeon mite infestation involving two patients, two nurses, and one physician on a medical ward in a municipal hospital. The index patient developed a diffuse, pruritic erythematous maculopapular rash on trunk and extremities. Dermanyssus gallinae, a blood-sucking avian mite was identified on the patient and his bedding. A second patient who complained of scalp pruritus had mites present on her pillow and bed linen. Pigeons roosting on the air conditioners and near the doors connecting the patients' rooms to a sun-porch were the source of the mites. Bellanger et al. (2008) in France described a case of nosocomial infestation with $D$. gallinae from an abandoned pigeon nest suspended on the front wall of the Hôpital Henri Mondor near a window. Close surveillance and regular destruction of pigeon nests prevented these incidents of human infection.

Apart from HDM nosocomial infection, scabies showed hospital transmission. Lerche et al. (1983) reported a person with an unrecognized case of atypical Norwegian scabies admitted to a community hospital in Chariton, Iowa. Twenty cases of symptomatic scabies were reported among hospital staff; mites were recovered from four. Subsequent evaluation confirmed scabies transmission to family and friends of this patient before hospitalization. The patient was successfully treated with $1 \%$ Lindane lotion, $10 \%$ Crotamiton lotion, and 6\% Sulfur ointment. Other cases in the hospital and community were treated with $10 \%$ Crotamiton which also was used to prophylactically treat exposed contacts. Larrosa et al. (2003) in Spain reported an 
outbreak of scabies occurred in a ward of a local hospital in Barbastro (Huesca, Spain), linked to a patient infested with mites when he was admitted to the ward. The outbreak was attributed to a delay in diagnosis, and lack of individual protection measures by caregivers.

\section{Conclusion}

Although, HDM grow well in a humid climate, this can be in well isolated dwellings or in the tropical climate and nourish from human skin dander. Proteins from its gastrointestinal tractknown as enzymes are allergens inducing chronic allergic diseases. Inhalation of small amounts of allergens on a regular base all night leads to a slow beginning of the disease with chronically stuffed nose and an exercise induced asthma which later on persists. An educational course designed for the nursing staff on house dust mites and allergy would be scientifically fruitful. Little is known by nursing experiences on HDM and allergic infection control in clinical setting despite its importance protecting patients and reducing risks of nosocomial exposure. Of course, the nursing staff is dealing with patients from rural and urban areas. So, to prevent allergic hospital infection, nurses should gain a better understanding of the cleaning care and adequately discharge these duties in daily practice.

This is the first report of national recovery of seven house dust mite in a military hospital. In a descending order of abundance, these were Dermatophagoides farinae, D. pteronyssinus, Ornithonyssus bacoti), Acarus siro, Tyrophagus putrescentiae, Laelaps nuttalli, and Parasitus consanguineus.

\section{Recommendations}

Although exposure to the house dust mite allergen is a major risk factor for allergic sensitization and asthma, mainly in children nationwide estimates of dust mite allergen levels in the Egyptian homes have not been reported. A mite map should be established by surveying of mite species in each HDM infested area.

1- Allergic patients should avoid exposure to indoor and outdoor dust.

2- The following house dust mites control measures are recommended: aRemoval of carpets from bed rooms of house dust sensitive patients, b- Cleaning of beds and carpets using advanced vacuum cleaner with high suction power, c- Vacuum mattress both sides for at least 2 minutes twice monthly to reduce dust and allergens in them, dEncasing pillows and mattresses in mite proof covers, e- Blankets \& pillow cases must be exposed to sun before kept in closed places, f- Dust frequently with a damp-cloth or furniture-dusting product, and g- Using the international acaricides safe dose in doors if indicated.

3- Skin prick test is a good negative test a screening test. Positive results should be confirmed by ELISA test.

4- Blood eosinophilia is an important laboratory test in diagnosing HDM atopic diseases.

5- Culturing of mite species from the Egyptian fauna to prepare specific antigens for allergic diagnosis and more species should be included in skin testing, as it might happen that some patients could be missed if only one or two species is tested. 
6- Regular educational program on house dust mites for the nursing students and newly employed ones is a must. This will minimize the risk of nosocomial mites' allergy.

\section{References}

Abdel-Salam, BK, 2013: Effect of different diets on Tyrophagus putrescentiae population and amelioration of their immunological disorder by garlic. Allergol. Immunopathol. (Madr). Jul 2. pii: S0301-0546(13)00145-6.

Adgate, JL, Banerjee, S, Wang, M, McKenzie, L, Hwang, J, et al, 2013: Performance of dust allergen carpet samplers in controlled laboratory studies. J. Expo. Sci. Environ. Epidemiol. 23, 4:385-91.

Adham, TM, Tawfik, SA, 2012: Dermatophagoides in childhood asthma. Allergy to dermatophagoides associates more severe childhood asthma with a potential role for acaricides. Saudi Med. J. 33, 3:292-7.

Arafa, SZ, Al-Hoot, AA, Hussein, H S, 2009: Pathological and ultrastructural studies on Anisakis simplex rudolphi1809 infecting Carangoides bajad with special reference to intestinal maturation in puppies. J. Egypt. Soc. Parasitol. 39, 2:607-16.

Arbes, SJ, Cohn, RD, Yin, M, Muilenberg, ML, Burge, HA, et al, 2003: House dust mite allergen in US beds: Results from the first national survey of lead and allergens in housing. J. Allergy Clin. Immunol. 111, 2:408-14.

Baker, ME, Morsy, TA, Nassef, NE, El-Meligi, M, 1995: Mites infesting commensal rodents in Menoufia Governorate, Egypt. J. Egypt. Soc. Parasitol. $25,3: 107-24$.
Becker, S, Gröger, M, Canis, M, Pfrogner, E, Kramer, MF, 2012: Tropomyosin sensitization in house dust mite allergic patients. Arch. Otorhinolaryngol. 269, 4:1291-6

Bellanger, AP, Bories, C, Foulet, F, Bretagne, S, Botterel, F, 2008: Nosocomial dermatitis caused by Dermanyssus gallinae. Infect. Control Hosp. Epidemiol. 29, 3:282-3.

Bernardini, R, Mistrello, G, Novembre, E, Roncarolo, D, Zanotta, S, et al, 2005: Cross-reactivity between IgEbinding proteins from Anisakis simplex and Dermatophagoides pteronyssinus. Int. J. Immunopathol. Pharmacol. 18, 4:671-5

Carrard, A, Pichler, C, 2012: House dust mite allergy. Ther. Umsch. 69, 4: 249-52.

El-Beshbishi, SN, Abdel-Magied, A A, El-Nahas, HA, Azab, MS, El-Shazly, AM, Morsy, ATA, 2005: Geoparasites in rural Dakahlia governorate, a preliminary based study for development of the community-based intervention programs. J. Egypt. Soc. Parasitol. 35, 3:1051-70.

El-Ghitany, EM, Abd El-Salam, M M, 2012: Environmental intervention for house dust mite control in childhood bronchial asthma. Environ. Hlth. Prev. Med. 17, 5:377-84.

El-Nahas, HA, El-Beshbishi, SN, Azab, MS, Zaalouk, T, Elsheikha, H, et al, 2007: Diagnostic criteria for HDM sensitized allergic patients. J. Egypt. Soc. Parasitol. 37, 3:S1113-24.

El-Shazly, AM, El-Beshbishi, S, Azab, M, EI Nahas, HA, Soliman, ME, et al, 2006: Present situation of HDM 
in Dakahlia Governorate Egypt. J. Egypt. Soc. Parasitol. 36, 1:113-26

El-Sherbiny, GT, El-Sherbini, ET, Saleh, NMS, Haridy, FM, Morsy, AT A, 2010: A study on the prevalence of house dust mites in Al-Arish city, North Sinai Governorate, Egypt. J. Egypt. Soc. Parasitol. 40, 1:57-70.

El-Zemity, S, Rezk, H, Farok, S, Zaitoon, A, 2006: Acaricidal activities of some essential oils and their monoterpenoidal constituents against house dust mite, Dermatophagoides pteronyssinus (Acari: Pyroglyphidae). J. Zhejiang Univ. Sci. B 7, 12:957-62

Feng, M, Yang, B, Zhuang, YJ, Yanagi, U, Cheng, XJ, 2012: A study on indoor environment contaminants related to dust mite in dwellings of allergic asthma patients and of healthy subjects. Biosci. Trends 6, 1:7-9.

Gamal-Eddin, FM, Tayel, SE, AbouSenna, FM, Shehata, K, 1982: Present status and ecology of house dust mites in Egypt as approaches to environmental control of mites and preparation of specific diagnostic antigen before resort to any desensitization vaccine. J. Egypt. Soc. Parasitol. 12:253-81.

Green, WF, Woolcock, AJ, 2006: $T y$ rophagus putrescentiae: An allergenic important mite. Clin. Exp. Allergy 8, 2: $135-44$.

Hatzivlassiou, M, Grainge, C, Kehagia, V, Lau, L, Howarth, PH, 2010: Allergen specificity of the late asthmatic reaction. Allergy 65, 3:355-8.

Larrosa, A, Cortés, M, Martínez, S, Clerencia, C, Urdániz, LJ, et al, 2003: Nosocomial outbreak of scabies in a hospital in Spain. Euro. Surveill. 8, 10:199-203.
Lerche, NW, Currier, RW, Juranek, DD, Baer, W, Dubay, NJ, 1983: A typical crusted Norwegian scabies: report of nosocomial transmission in a community hospital and an approach to control. Cutis 31, 6:637-42.

Macan, J, Kanceljak-Macan, B, Milković-Kraus, S, 2012: Pyroglyphid mites as a source of work-related allergens. Arh. Hig. Rada Toksikol. 63, 1: S57-66.

Mazyad, SA, Mohammad, KA, Khalil, HH, 2006: Allergic reactions in patients suffering from asthma induced by house dust mites which treatment by juvenile hormone. J. Egypt. Soc. Parasitol. 36, 2:S31-48.

Morsy, TA, El Said, AM, Salama, M I, Arafa, MAS, Younis, TA, et al, 1995: Four species of house dust mites from houses of patients with allergic respiratory diseases. J. Egypt. Soc. Parasitol. 25, 1:199-206.

Morsy, TA, Zohdi, HW, Abdalla, K F, El-Fakahany, AF, Ibrahim, AA, et $a l$, 1994: Isolation of three species of mites from house dust of atopic dermatitis patients in Qualyobia G, Egypt. J. Egypt. Soc. Parasitol. 24:323-32.

Netusil, J, Zákovská, A, Horváth, R, Dendis, M, Janouskovcová, E, 2005: Presence of Borrelia burgdorferi sensu lato in mites parasitizing small rodents: Vect. Borne Zoonotic Dis. 5, 3:227-32.

Park, SY, Jing, X, Gupta, D, Dziarski, R, 2013: Peptidoglycan recognition protein 1 enhances experimental asthma by promoting Th 2 and Th17 and limiting regulatory $\mathrm{T}$ cell and plasmacytoid dendritic cell responses. J. Immunol. 190, 7:3480-92. 
Ramìrez-Heredia, J, Oífarrill-Romanillos, PM, Fogelbach, G, Nakamura, RK, Segura, NH, 2013: Sensitization to house dust and storage mites in allergic adults from the South of Mexico city. Rev. Allerg. Mex. 60, 1:31-7.

Reeves, WK, Loftis, AD, Szumlas, D, Abbassy, M, Helmy, IM, et al, 2007: Rickettsial pathogens in the tropical rat mite Ornithonyssus bacoti (Acari: Macronyssidae) from Egyptian rats (Rattus). Exp. Appl. Acarol. 41, 1/2:101-7.

Regan, AM, Metersky, ML, Craven, DE, 1987: Nosocomial dermatitis and pruritus caused by pigeon mite infestation. Arch. Int. Med. 147, 12:2185-7.

Saad, el-Z, Hussien, R, Saher, F, Ahmed, Z, 2006: Acaricidal activities of some essential oils and their monoterpenoidal constituents against house dust mite, D. pteronyssinus (Pyroglyphidae). J. Zhejiang Univ. Sci. 7, 12: 957-62.

Sadaka, HAH, Allam, SR, Rezk, HA, EI Nazer, SY, Shola, AY, 2000: Isolation of dust from houses of Egyptian allergic patients and induction of experimental sensitivity by $D$ pteronyssinus. J. Egypt. Soc. Parasitol. 30, 1:263-76.

Salehi, M, Moradi, S, Chavoshzadeh, Z, Gorji, FA, Khoramrooz, Z, 2011: A study of home characteristics in children with allergic rhinitis and asthma. Acta Clin. Croat. 50, 2:225-7.

Shanbaky, NM, Hammad, RE, 1989: Determination and seasonal abundance of mite predators of the house fly eggs in Cairo and Giza, Egypt. J. Egypt. Soc. Parasitol. 19, 2:551-62.

Solarz, K, 2009: Indoor mites and the forensic acarology. Exp. Appl. Acarol. 49, 1/2:135-42.
Szafranek, P, Lewandowski, M, Kozak, M, 2013: Prey preference and life tables of the predatory mite Parasitus bituberosus (Acari: Parasitidae) when offered various prey combinations. Exp. Appl. Acarol. 61, 1:53-67.

Szlendak, E, Lewandowski, M, 2009: Development and reproductive capacity of the predatory mite Parasitus consanguineus reared on larvae of $\mathrm{Me}$ gaselia halterata and Lycoriella ingenua. Exp. Appl. Acarol. 47, 4:285-92.

Valmonte, GR, Cauyan, GA, Ramos, JD, 2012: IgE cross-reactivity between house dust mite allergens and Ascaris lumbricoides antigens. Asia Pac. Allergy 2, 1:35-44.

Yassin, MK, 2011: Allergenic Dermatophagoides mites causing asthma among schoolchildren at Ain-Shams District, Cairo, Egypt. J. Egypt. Soc. Parasitol. 41, 1: 47-54.

Yassin, MK, Rifaat, MM, 1997: Distribution and abundance of house dust mites, Dermatophagoides spp., in different ecological localities in Esna City, Kena Governorate, Egypt. J. Egypt. Soc. Parasitol. 27, 2:431-7.

Yuenyongviwat, A, Koonrangsesomboon, $D$, Sangsupawanich, $P, 2013$ : Recent 5-year trends of asthma severity and allergen sensitization among children in southern Thailand. Asian Pac. J. Allergy Immunol. 31, 3:242-6.

Zieglmayer, UP, Horak, F, Toth, J, Marks, B, Berger, UE, et al, 2005: Efficacy and safety of an oral formulation of cetirizine and prolonged-release pseudoephedrine versus budesonide nasal spray in the management of nasal congestion in allergic rhinitis. Treat Respir. Med. 4, 4:283-7. 